Article

\title{
Development of Selenized Lactic Acid Bacteria and their Selenium Bioaccummulation Capacity
}

\author{
Gabriela Krausova ${ }^{1, *}$, Antonin Kana ${ }^{2}{ }^{\circledR}$, Ivana Hyrslova ${ }^{1}$, Iva Mrvikova ${ }^{1}$ and \\ Miloslava Kavkova ${ }^{1}$ \\ 1 Department of Microbiology and Technology, Dairy Research Institute, Ltd., Ke Dvoru 12a, 16000 Prague, \\ Czech Republic; hyrslova@milcom-as.cz (I.H.); mrvikova@milcom-as.cz (I.M.); \\ m.kavkova@vum-tabor.cz (M.K.) \\ 2 Faculty of Chemical Engineering, University of Chemistry and Technology Prague, Technicka 5, \\ 16628 Prague, Czech Republic; Antonin.Kana@vscht.cz \\ * Correspondence: krausova@milcom-as.cz; Tel.: +420-773088810
}

Received: 18 August 2020; Accepted: 18 September 2020; Published: 21 September 2020

\begin{abstract}
Selenized lactic acid bacteria (LAB) represent potentially safe and effective sources of selenium (Se), essential for human health, as lactic acid fermentation improves Se bioavailability and reduces its toxicity. LAB are generally recognized as safe (GRAS) and widely used in fermented dairy products. To facilitate selenized LAB implementation as a functional food, we developed and characterized new Se-enriched strains based on the food industry commercial strains Streptococcus thermophilus CCDM 144 and Enterococcus faecium CCDM 922A as representatives of two LAB genera. We evaluated Se bioaccumulation capacity, Se biotransformation and growth ability in the presence of different sodium selenite concentrations $(0-50 \mathrm{mg} / \mathrm{L})$, and antioxidant properties (2, 2-diphenyl-1-picrylhydrazyl (DPPH) method) and cell surface hydrophobicity between Se-enriched and parental strains in vitro. Sodium selenite addition did not negatively influence growth of either strain; thus, $50 \mathrm{mg} / \mathrm{L}$ was chosen as the optimal concentration based on strain accumulation capacity. Selenization improved the antioxidant properties of both strains and significantly increased their cell surface hydrophobicity $(p<0.05)$. To our knowledge, this represents the first report of Se-enriched strain hydrophobicity as well as the first on Se speciation in families Enterococcaceae and Streptococcaceae. Moreover, both tested strains demonstrated good potential for Se-enrichment, providing a foundation for further in vitro and in vivo studies to confirm the suitability of these Se-enriched strains for industrial applications.
\end{abstract}

Keywords: selenium; bioaccummulation; selenization; Streptococcus thermophilus; Enterococcus faecium; antioxidant activity; hydrophobicity

\section{Introduction}

Lactic acid bacteria (LAB) are a natural part of the gastrointestinal tract of healthy individuals and also serve as an integral part of the food industry, wherein their properties and synergisms affect the rheological, sensory, and probiotic properties of dairy, bakery, and meat products. Moreover, the development of selenium-enriched forms of LAB is gaining attention in the search for safe and effective sources of selenium (Se) because LAB exhibit high absorption potential for metal ions, including Se [1]. As an essential trace element for human health, Se supplementation via foods and dietary supplements is frequently necessary, especially in locations with lower Se concentrations in the soil including southern and eastern European countries [2]. In particular, Se exhibits important antioxidant activity, thereby protecting cells from oxidative stress. Selenium deficiency is closely associated with thyroid dysfunction, as Se (in the form of selenocysteine) is a component of the enzymes 
thioredoxin reductase and iodothyronine deiodinase [3]. In the form of seleno-amino acids, Se also serves as a component of other selenoproteins and selenoenzymes, of which the most important is glutathione peroxidase, a key antioxidant enzyme, for which Se acts as a cofactor [4]. Nevertheless, although Se is a natural component of the biosphere and essential for life, a very narrow line exists between the concentration at which this element is still beneficial and that at which it is toxic. The main concern with Se administration is thus nephrotoxicity, as this element accumulates in the kidneys, liver, and other organs. The inorganic forms of Se (SeIV, SeVI) are the most toxic, although these are permitted in food supplements and foodstuffs in Europe in the form of sodium selenite $\left(\mathrm{Na}_{2} \mathrm{SeO}_{3}\right)$, sodium hydrogen selenite, and sodium selenate [5].

Notably, some strains of LAB, bifidobacteria, and yeast are able to bind, capture, and biotransform Se from the growth medium [1] and detoxify inorganic Se to its elemental or organic forms, such as selenocysteine, selenomethionine, or methylselenocysteine [6,7]. It has thus been possible to develop Se-enriched LAB, probiotics, or yeasts and thereby increase the health benefits and nutritional value of foods containing these beneficial microorganisms. In turn, the concept of Se-enriched probiotics involves combining and multiplying the individual health effects on the body, together with providing a nutritional advantage through supplementation of this essential microelement. The beneficial effects of Se-enriched strains have been documented in several in vitro and in vivo studies [8] and their antioxidant, antimutagenic, antimicrobial, anticarcinogenic, and anti-inflammatory effects have been observed $[9,10]$. In particular, yeasts, especially Saccharomyces cerevisiae, have been widely investigated with regard to Se enrichment and biotechnological studies [11-13], especially as Se-enriched yeast, which contains Se in organic form ( $\geq 99 \%)$, is also permitted for use in food and food supplements in EU countries [5].

LAB also represent a promising target group for selenization [14-16], as these microbes produce various antimicrobial compounds such as organic acids, hydrogen peroxide, and bacteriocins, which possess antimicrobial activity by means of the different metabolic substances generated [17]. However, as Se-enriched LAB are not yet legislatively permitted for use in foods, it is necessary to obtain additional information regarding their safety, functionality, and properties. To this end, we hypothesized that the choice of strains already in use in the commercial food industry, especially in dairy processing plants and exhibiting promising probiotic features and technological features, might jumpstart this process. In particular, Enterococcus faecium CCDM 922A exhibits immunomodulatory abilities, good adhesion properties, and the capacity to reduce low density lipoprotein and very low density lipoprotein cholesterol in rats [18]. This strain also harbors a gene encoding a class IIa bacteriocin (enterocin $\mathrm{A}$, in preparation). Enterococcus is one of the main genera belonging to the LAB group, with nearly 50 species [19]. They play a technological role in several fermented food products owing to their contribution to the safety and sensory characteristics of the production of organic acids, antimicrobial compounds, and aromatic volatile compounds [20]. Despite all the positive qualities mentioned, it is necessary to add that the species Enterococcus faecium is not granted with the QPS (Qualified Presumption of Safety) status [21] which means that the safety of each strain must be assessed individually.

In turn, Streptococcus salivarius subsp. thermophilus (in practice, referred to as S. thermophilus) is the only streptococcal species associated with food technology [22]. It is a widespread exopolysaccharide (EPS)-producing bacterium used in the production of fermented dairy products to improve their texture [23]. Both S. thermophilus CCDM 144 and E. faecium CCDM 922A belong to the LAB group that confers the positive technological properties of fermented products, contributing to product texture by producing EPS. In addition, these strains test positive for the presence of $b s h$ genes (in preparation), which are responsible for bile salt hydrolase activity, an important feature of potential probiotic strains in the detoxification of bile salts [20].

In this study, we therefore aimed to develop Se-enriched strains of S. thermophilus CCDM 144 and E. faecium CCDM 922A and compare the properties of the selenized and parental strains including their antioxidant properties and cell surface hydrophobicity. Furthermore, their Se accumulation capacity, Se 
biotransformation, ability to grow at different concentrations of sodium selenite in the growth medium, and lactic acid production were evaluated.

\section{Materials and Methods}

\subsection{Bacterial Strains}

S. thermophilus CCDM 144 and E. faecium CCDM 922A, originating from the Culture Collection of Dairy Microorganisms (CCDM) Laktoflora ${ }^{\circledR}$ (Tábor, Czech Republic) were used in this study to evaluate their potential to uptake and accumulate Se, antioxidant activity, hydrophobicity, and Se enrichment. Both strains were grown in M17 broth acc. to Terzaghi (Merck, Germany) or on M17 agar acc. to Terzaghi (Merck, Germany) for enumeration and aerobically cultivated at $37^{\circ} \mathrm{C}$ for $24-48 \mathrm{~h}$. For enumeration, the plate count method was applied using a 10-fold dilution on M17 agar for both strains with cultivation as described above. For all analyses, the strains CCDM 144 and CCDM 922A grown in selenite-free M17 cultivation medium were used as controls.

\subsection{Strain Confirmation Using $16 S$ rRNA}

Bacterial DNA was isolated from $1 \mathrm{~mL}$ of supernatant obtained by centrifugation $(15,000 \times g$ for 10 min, Spectrafuge 6C, Labnet International, Edison, NJ, USA) of the bacterial suspensions grown overnight. Then, the pellet was washed and resuspended in 0.1 mol Rinsen solution (Sigma-Aldrich, St. Louis, MO, USA) and centrifuged again. After repeating this procedure twice, the cells were washed twice with polymerase chain reaction (PCR)-grade water (Top Bio, Vestec, Czech Republic). Alkaline lyse solution $(100 \mu \mathrm{L}, 0.05 \mathrm{~mol} \mathrm{NaOH}, 0.25 \%$ sodium dodecyl sulfate) was used for lysing the sediment. After boiling the cell solutions for $30 \mathrm{~min}$ at $94{ }^{\circ} \mathrm{C}$, the samples were diluted 50-fold with PCR-grade water and stored at $-20^{\circ} \mathrm{C}$. Microbial DNA was isolated using a commercial UltraClean ${ }^{\mathrm{TM}}$ Microbial DNA Isolation Kit (MO BIO, Carlsbad, CA, USA) following the manufacturers' instructions.

The primers used for amplification of the $16 \mathrm{~S}$ rRNA genes were fD1 (5'-ccg aat tcg tcg aca acA GAG TTT GAT CCT GGC TCA G-3') and rP2 (5'-ccc ggg atc caa gct tAC GGC TAC CTT GTT ACG ACT T-3') [24], where linker sequences for cloning are shown in lower case letters. PCR reactions were performed in $25 \mu \mathrm{L}$ reactions consisting of PCR-grade water $(10.5 \mu \mathrm{L})$, PPP Master Mix $(12.5 \mu \mathrm{L}$; Top-Bio), primers (10 pmol/ $\mu \mathrm{L}) \mathrm{fD} 1$ and rP2 (0.5 $\mu \mathrm{L}$; Generi Biotech, Třebeš, Czech Republic), and $1 \mu \mathrm{L}$ template. A Biometra thermal cycler (Biometra $\mathrm{GmbH}$, Göttingen, Germany) was used for PCR amplification ( 35 cycles): initial denaturation: $95^{\circ} \mathrm{C}$ for $90 \mathrm{~s}, 94{ }^{\circ} \mathrm{C}$ for $30 \mathrm{~s}, 55^{\circ} \mathrm{C}$ for $30 \mathrm{~s}, 72{ }^{\circ} \mathrm{C}$ for $60 \mathrm{~s}$; final extension: $72{ }^{\circ} \mathrm{C}$ for $10 \mathrm{~min}$. The PCR products stained with GelRed ${ }^{\circledR} \mathrm{Nucleic}$ Acid Stain (Biotium $^{\circledR}$, Fremont, CA, USA) were visualized on $1 \%$ agarose under UV light. Subsequently, the PCR products were diluted in ExoSap-IT ${ }^{\mathrm{TM}}$ (AppliedBiostems, Lithuania) at a ratio of 1:10. Then, $15 \mu \mathrm{L}$ of the solution was mixed with $2 \mu \mathrm{L}$ forward/reverse primers and sent to GATC Biotech (Ebersberg, Germany) for LightRun sequencing using the Sanger method. The amplicons were prepared according to service instructions and sequenced by the Eurofins Genomics Service (Ebersberg bei München, Germany). The sequences were edited using BioEdit software. The obtained 16S rDNA sequences were compared with data from the GEN Bank/EMBL/DDBJ/PDB databases using the Blast program [25]. Sequence homology at $98-100 \%$ was taken as the limit to match the taxonomic unit to the sample [26].

\subsection{Preparation of Se-Enriched Strains, Enumeration, and Optical Density (OD)}

First, the concentration of selenite applicable to the medium without inhibiting bacterial growth was determined for both strains. Fresh, overnight-grown cultures in a final concentration of $10^{5} \mathrm{CFU} / \mathrm{mL}$ of both bacterial suspensions were inoculated into the media (M17; Merck, Darmstadt, Germany) with the addition of $0,1,5,10,30$, and $50 \mathrm{mg} / \mathrm{L}$ of sodium selenite (Sigma-Aldrich, St. Louis, MO, USA). After $24 \mathrm{~h}$ of aerobic cultivation at $37^{\circ} \mathrm{C}$, bacterial counts were determined using the plate count method with a 10-fold dilution, followed by measuring the OD of the bacterial suspensions at a wavelength of $620 \mathrm{~nm}$ (ONDA V-10 Plus, Giorgio Bormac, Carpi, Italy) and by measuring the 
$\mathrm{pH}$ ( $\mathrm{pH}$ meter sensION1, HACH, Loveland, CO, USA) of the culture medium. After cultivation, the cells were centrifuged at $4100 \times g$ for $10 \mathrm{~min}$ (Spectrafuge 6C; Labnet International) and the samples were lyophilized (Lyobeta 35; Telstar, Barcelona, Spain) to determine the total amount of Se bound to bacterial cells. In this manner, the Se-enriched biomass of both strains was used to determine the total amount of Se uptake by individual strains.

\subsection{Lactic Acid Production}

Concentrations of lactic acid as the main fermentation product of LAB were measured isotachophoretically (IONOSEP 2003; Recman, Ostrava, Czech Republic). Prior to analysis, the samples were diluted with $150 \times$ of deionized water and then purified using the Puradisc FP 30 filter with a pore size of $0.2 \mu \mathrm{m}$ (Whatman, Germany). A solution containing $10 \mathrm{mmol} / \mathrm{L} \mathrm{HCl}, 22 \mathrm{mmol} / \mathrm{L} \varepsilon$-aminocaproic acid, and $0.1 \%$ 2-hydroxy-ethylcellulose ( $\mathrm{pH} 4.5$ ) as the leading electrolyte (LE) was used. Additionally, $5 \mathrm{mmol} / \mathrm{L}$ caproic acid was used as the trailing electrolyte (TE). All chemicals were obtained from Sigma-Aldrich (St. Louis, MO, USA). The values of the initial and final streams used were 80 and $30 \mu \mathrm{A}$, respectively. The amount of lactic acid produced by the tested strains was calculated as the difference in the concentration of lactic acid after and before fermentation and is expressed in $\mathrm{mg} / 100 \mathrm{~mL}$. Results represent the average of triplicate measurements.

\subsection{Determination of Total Se Content}

The total amount of bound Se was determined in the lyophilized biomass of each strain by inductively coupled plasma mass spectrometry (ICP-MS) after microwave-assisted acid digestion. A weighed lyophilized and homogenized sample was placed in a Teflon ${ }^{\circledR}$ digestion vessel, $3 \mathrm{~mL}$ of concentrated nitric acid (67\% Analpure ${ }^{\circledR}$, Analytika spol. s r.o., Prague, Czech Republic) was added, and the mixture was mineralized in a closed vessel in a microwave digestion system (Speedwave 4; Berghof, Germany) for $10 \mathrm{~min}$ at $240{ }^{\circ} \mathrm{C}$. After cooling, the decomposed sample was transferred to a $50 \mathrm{~mL}$ volumetric flask, an internal standard $(100 \mu \mathrm{L}$ of $1 \mathrm{mg} / \mathrm{L} \mathrm{Rh})$ was added, and the flask was filled to the mark with demineralized water (Milli-Q, Millipore, Billerica, MA, USA). The ICP-MS (DRC-e; Perkin-Elmer, Canada) measurement conditions were as follows: RF power $1.4 \mathrm{~kW}$, nebulizer gas flow rate $0.76 \mathrm{~L} / \mathrm{min}$, auxiliary gas flow rate $1 \mathrm{~L} / \mathrm{min}$, plasma gas flow rate $11 \mathrm{~L} / \mathrm{min}$, measured isotopes ${ }^{80} \mathrm{Se}$ (analyte) and ${ }^{103} \mathrm{Rh}$ (internal standard). The spectral interference of ${ }^{40} \mathrm{Ar}_{2}{ }^{+}$was eliminated using a dynamic reaction cell with methane as the reaction gas (methane flow rate $0.3 \mathrm{~mL} / \mathrm{min}$, rejection parameter $q 0.5)$.

\subsection{Determination of Se Species}

Portions of the freeze-dried samples were placed into $15 \mathrm{~mL}$ polypropylene tubes and extracted with $9 \mathrm{~mL}$ of $20 \mathrm{mmol} / \mathrm{L}$ Tris- $\mathrm{HCl}$ buffer ( $\mathrm{pH} 7.5$ ) containing $2.0 \mathrm{~g} / \mathrm{L}$ of protease XIV (Sigma Aldrich, Steinheim, Germany) for $24 \mathrm{~h}$ at $37^{\circ} \mathrm{C}$. The extracts were cooled to $5^{\circ} \mathrm{C}$, filtered through a $0.45 \mu \mathrm{m}$ Nylon ${ }^{\circledR}$ filter (Labicom, Olomouc, Czech Republic) and analyzed directly by liquid chromatography (HPLC) (Series 200; Perkin-Elmer, Shelton, USA) coupled to ICP-MS. Methodology for separation of Se species were adapted from Eichler et al. [27] with small modifications. Se species were separated using a RP-C8 HPLC column (Purospher STAR-C8e, $250 \times 4.6$ mm, $5 \mu \mathrm{m}$; Merck, Darmstadt, Germany) and the mobile phase consisted of $1.0 \mathrm{~g} / \mathrm{L}$ sodium butane-1-sulfonate, $0.22 \mathrm{~g} / \mathrm{L}$ tetramethylammonium hydroxide pentahydrate, $0.42 \mathrm{~g} / \mathrm{L}$ malonic acid and $0.05 \%$ (v/v) methanol (all Sigma Aldrich, Steinheim, Germany). The HPLC conditions were as follows: mobile phase flow rate $1 \mathrm{~mL} / \mathrm{min}$, injection loop volume $50 \mu \mathrm{L}$, temperature $20^{\circ} \mathrm{C}$. The ICP-MS conditions were identical to the conditions used for total Se determination in paragraph 2.5 without using ${ }^{103} \mathrm{Rh}$ as internal standard. Calibration solutions were prepared by multiple dilutions of stock solutions of Se species (sodium selenate (SeVI), sodium selenite (SeIV), selenocystine (SeCys2), selenomethionine (SeMet), Se-methylselenocysteine (MeSeCys) were obtained from Sigma Aldrich, Steinheim, Germany) with demineralized water, giving concentrations of $1 ; 5 ; 10$ and $20 \mu \mathrm{g} / \mathrm{L}$ Se of each species. 


\subsection{DPPH Radical-Scavenging Activity/Antioxidant Activity}

The 2, 2-diphenyl-1-picrylhydrazyl (DPPH) radical scavenging ability was determined using the methods of Rajab et al. [28] and Son et al. [29] with slight modifications. Briefly, overnight-grown strains cultivated in medium with or without sodium selenite were centrifuged at $6000 \times g$ for 8 min at room temperature. The obtained bacterial cells were washed twice with phosphate buffered saline (PBS) ( $\mathrm{pH} 7.4$; Sigma-Aldrich, Czech Republic), and resuspended at a final concentration of $10^{7}-10^{8} \mathrm{CFU} / \mathrm{mL}$. Then, $1 \mathrm{~mL}$ of resuspended cells and $3 \mathrm{~mL}$ of $0.1 \mathrm{mmol} / \mathrm{L}$ DPPH solution in ethanol were mixed and incubated for $30 \mathrm{~min}$ at room temperature in the dark. The negative control $\left(\mathrm{A}_{\mathrm{c}}\right)$ contained only PBS, whereas the positive control contained butylated hydroxytoluene (BHT) and DPPH. Subsequently, the samples $\left(\mathrm{A}_{\mathrm{S}}\right)$ were measured spectrophotometrically at $\mathrm{OD}_{517}$ using the Spectrophotometer ONDA V-10 Plus device (Giorgio Bormac, Carpi, Italy). The DPPH radical scavenging activity (\%) of the tested strains was calculated using the following formula:

$$
\left(1-A_{S} / A_{c}\right) \times 100
$$

\subsection{Hydrophobicity}

To determine the hydrophobicity of the CCDM 144 and CCDM 922A strains, the microbial adhesion to hydrocarbons (MATH) method by Vinderola et al. [30] was used. The overnight grown bacterial suspensions in M17 broth of each strain (both selenized and parental) were harvested by centrifugation at $6000 \times g$ for $8 \mathrm{~min}$ at room temperature. The cells were washed twice using phosphate buffer ( $\mathrm{pH}$ 6.6) and adjusted to an OD of $0.55-0.60$ at $600 \mathrm{~nm}\left(\mathrm{H}_{0}\right)$. To determine the hydrophobicity of the cell surface, hexane was used as a solvent; this was added to the cell suspension and vortexed for $1 \mathrm{~min}$. Then, phase stabilization and separation (10 $\mathrm{min}$, room temperature) were performed. Subsequently, the OD of the aqueous phase was measured at $600 \mathrm{~nm}\left(\mathrm{H}_{1}\right)$. The hydrophobicity values (\%) were calculated according to:

$$
\mathrm{H}=\left(\left(\mathrm{H}_{0}-\mathrm{H}_{1}\right) / \mathrm{H}_{0}\right) \times 100
$$

The values given are the average of three measurements.

\subsection{Statistical Analyses}

To evaluate the results, Statgraphics ${ }^{\circledR}$ Centurion XV (StatPoint, Inc., Warrenton, VA, USA) was used to calculate analysis of variance (ANOVA) with a post hoc least significance difference test (LSD) for multiple comparisons, considering statistical significance at the level of $p<0.05$.

\section{Results and Discussion}

\subsection{Confirmation of S. thermophillus CCDM 144 and E. faecium CCDM 922A Strain Identity}

In this study, we evaluated two LAB strains for selenization capacity and resultant in vitro characteristics: S. thermophillus CCDM 144 and E. faecium CCDM 922A. Both are used as probiotic or starter cultures in foods and foodstuffs and are of high industrial relevance. Prior to the experiment, the strains were precisely identified by means of sequencing their 16S rRNA bacterial DNA and comparison with the respective reference strain, confirming strain CCDM 144 as S. thermophilus with $100 \%$ identity and strain CCDM 922A as E. faecium with 99\% identity. This was consistent with the established criterion for the evaluation of individual specimens, wherein the difference in nucleotide sequence between the reference strain in the database and the assessed sample should not differ by more than $2 \%$ (probability $98 \%$ ) [26]. 


\subsection{Selenization of S. thermophillus CCDM 144 and E. faecium CCDM 922A Strains}

For the preparation of selenized forms of the two strains, it was necessary to choose a suitable concentration of sodium selenite that would not inhibit the bacterial growth while ensuring sufficient accumulation of Se in the cells. Sodium selenite concentrations ranging from $0,1,5,10,30$, and $50 \mathrm{mg} / \mathrm{L}$ were tested. As a control, a medium without the addition of sodium selenite $(0 \mathrm{mg} / \mathrm{L})$ was used. Analyses of Se content in the lyophilized bacterial biomass of both strains showed that they were able to markedly accumulate this microelement, with the ability increasing with increasing sodium selenite concentrations in the M17 cultivation medium (Table 1). The total amount of accumulated Se after $24 \mathrm{~h}$ cultivation was monitored and the OD of bacterial suspensions, lactic acid production, and $\mathrm{pH}$ of the cultivation media were determined. The CCDM 144 strain accumulated the most Se at a concentration of $50 \mathrm{mg} / \mathrm{L}$ sodium selenite $(7348 \mu \mathrm{g} / \mathrm{g})$, with no inhibition of bacterial growth observed even at the highest selenite concentration used $(50 \mathrm{mg} / \mathrm{L})$. Similarly, the strain CCDM 922A exhibited the best accumulation capacity at $50 \mathrm{mg} / \mathrm{L}$ sodium selenite $(6491 \mu \mathrm{g} / \mathrm{g})$. In comparison, Pieniz et al. [31] reported a high level of accumulated selenite in Enterococcus durans, reaching a maximum of $9128 \mu \mathrm{g} / \mathrm{L}$ at a selenite concentration of $60 \mathrm{mg} / \mathrm{L}$; specifically, the highest percentage of Se was found in the protein fraction, followed by polysaccharides and nucleic acids.

Table 1. Influence of sodium selenite $\left(\mathrm{Na}_{2} \mathrm{SeO}_{3}\right)$ concentration on viability, $\mathrm{pH}$, lactic acid production, and selenium binding ability of the CCDM 144 and CCDM 922A strains.

\begin{tabular}{cccccc}
\hline $\begin{array}{c}\text { Strain + Na } \\
(\mathbf{m g} / \mathbf{L})\end{array}$ & $\begin{array}{c}\text { Selenium } \\
\text { Content }(\boldsymbol{\mu g} / \mathbf{g})\end{array}$ & $\begin{array}{c}\text { Optical Density } \\
\mathbf{( 6 2 0} \mathbf{~ n m})\end{array}$ & $\begin{array}{c}\text { Viable Counts } \\
(\mathbf{l o g} \mathbf{C F U} / \mathbf{m L})\end{array}$ & $\mathbf{p H}$ & $\begin{array}{c}\text { Lactic Acid } \\
(\mathbf{m g} / \mathbf{L})\end{array}$ \\
\hline $144-0$ & $<\mathrm{LOD}$ & 7.82 & 7.68 & 5.81 & 389 \\
$144-1$ & $38 \pm 13$ & 7.91 & 7.65 & 5.80 & 385 \\
$144-5$ & $330 \pm 132$ & 7.72 & 7.32 & 5.81 & 385 \\
$144-10$ & $956 \pm 309$ & 7.79 & 7.38 & 5.81 & 388 \\
$144-30$ & $5172 \pm 1630$ & 7.79 & 7.36 & 5.82 & 390 \\
$144-50$ & $7348 \pm 2395$ & 7.77 & 7.33 & 5.81 & 397 \\
$922 \mathrm{~A}-0$ & $0.20 \pm 0.07$ & 9.08 & 8.93 & 5.67 & 300 \\
$922 \mathrm{~A}-1$ & $33.4 \pm 8.7$ & 9.51 & 9.00 & 5.68 & 289 \\
$922 \mathrm{~A}-5$ & $248 \pm 39$ & 9.11 & 8.71 & 5.68 & 318 \\
$922 \mathrm{~A}-10$ & $464 \pm 70$ & 9.19 & 8.95 & 5.69 & 292 \\
$922 \mathrm{~A}-30$ & $4595 \pm 711$ & 9.23 & 8.81 & 5.66 & 299 \\
$922 \mathrm{~A}-50$ & $6491 \pm 1158$ & 9.22 & 8.00 & 5.65 & 296 \\
\hline
\end{tabular}

Values are the average \pm standard deviations of duplicated independent experiments. LOD-limit of detection.

$\mathrm{LAB}$ are able to concentrate Se intracellularly in organic forms but also as elemental Se owing to the activation of the detoxification mechanism that reduces tetravalent Se to elemental Se [32]. Additionally, LAB strains have the ability to cleave proteins in milk and milk products and thus contribute to increasing the bioaccessibility of Se [33]. The added sodium selenite is metabolized via the following possible pathways: (a) methylation coupled with the reduction of Se, or (b) direct Se incorporation or binding to proteins replacing sulfur by Se in cysteine and methionine [34]. The binding of metal ions and their transport and storage in the cells of LAB are mediated by complex processes that depend on the characteristics of the metal ions, the specific physiological properties of individual strains, and the cultivation medium [1]. Moreover, as demonstrated by a previous study [16], Se accumulation capacity can be influenced by factors such as $\mathrm{pH}$, inoculum dose, culture temperature, and individual strain abilities.

Published data on selenium speciation in microorganisms belonging to order Lactobacillales are limited to family Lactobacillaceae, and to the best of our knowledge, Se speciation in families Enterococcaceae and Streptococcaceae has not been described yet. Se species were determined in Se-fortified strains only because the Se content was very low for speciation analysis in control strains. The extract of CCDM 144 strain (Figure 1A) contained predominantly SeMet (22-35\% of total Se in 
extract) and only small amount on inorganic form of selenium (4-7\% of total Se in extract). Other Se species (60-73\% of total Se in extract) were not identified, but we suppose that these are organic Se species. Under this assumption, the abundance of organically bound Se reached $93-96 \%$. A different speciation was observed for the CCDM 922A strain (Figure 1B). The lower abundance of SeMet (5-18\% of total Se in extract) were observed in comparison to CCDM 144, but also MeSeCys (2-10\% of total Se in extract) was found. The amount of the inorganic form of selenium (3-9\% of total Se in extract) was similar. Other Se species (66-82\% of total Se in extract) were not identified again. The percentage of organically bound Se reached $91-98 \%$. Regarding the abundance of individual selenium species, no dependence on the concentration of added selenite was observed. It should also be noted that the extraction efficiency was on average only $18 \%$ and therefore the real values (assuming 100\% extraction efficiency) of the percentage of individual species may be slightly different from those measured. Compared to published data for the Lactobacillaceae family [35-37], SeCys2 was not found in CCDM 144 and CCDM 922A strains. On the other hand, MeSeCys was found in all samples of various Lactobacillus [35,36,38] and Pediococcus acidilactici [37] while the CCDM 144 strain did not contain MeSeCys.
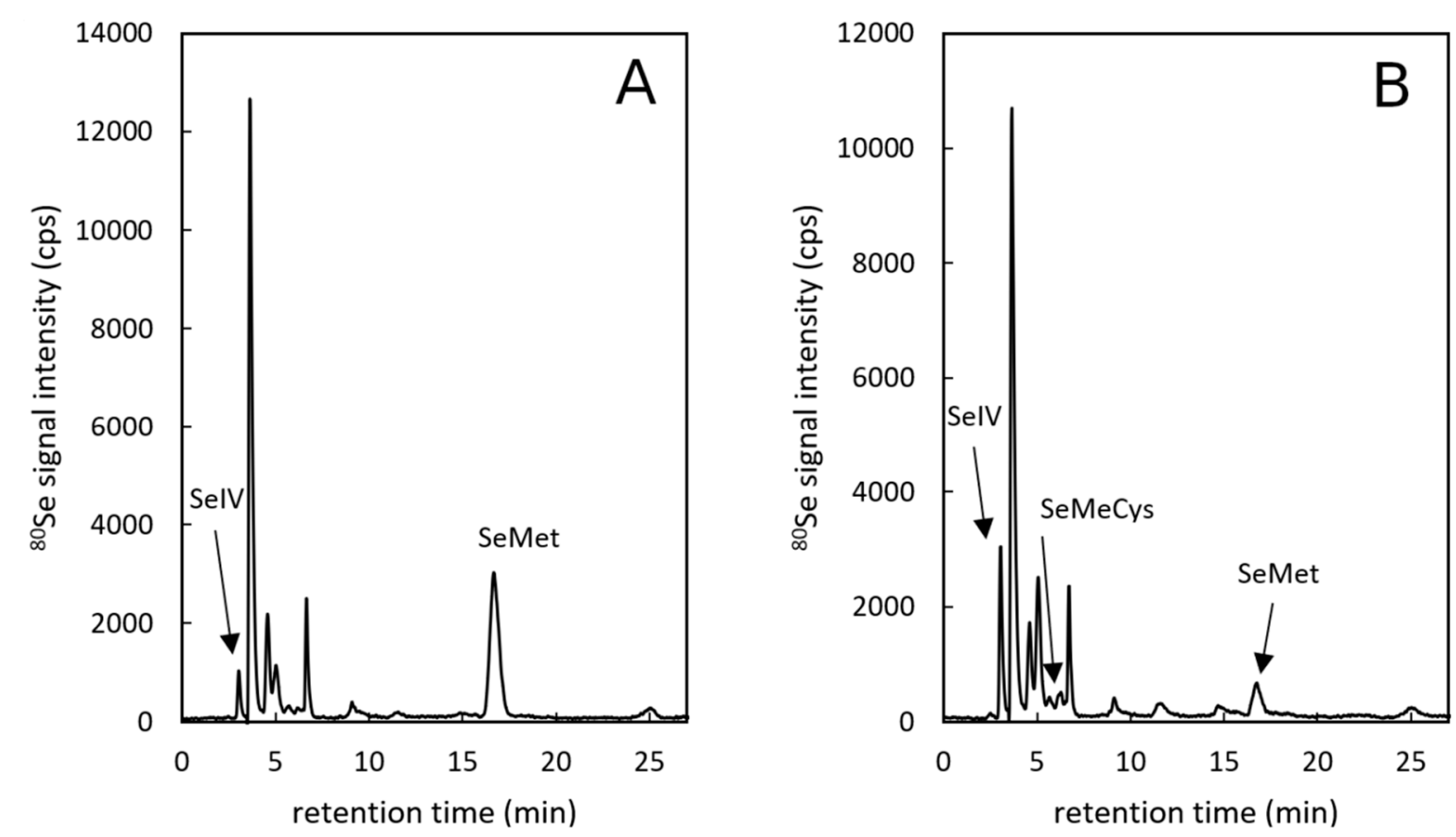

Figure 1. HPLC-inductively coupled plasma (ICP)-MS chromatograms of CCDM 144 (144-5) strain extract (A) and CCDM 922A (922-5) strain extract (B).

\subsection{Effects of S. thermophillus CCDM 144 and E. faecium CCDM 922A Selenization on Cell Viability and Growth}

Bacterial viability was determined by counting colony-forming units (CFU/mL). Both strains showed an increase in bacterial cell counts after $24 \mathrm{~h}$ incubation in media containing different concentrations of sodium selenite, with five different exposure concentrations $(1,5,10,30$, and $50 \mathrm{mg} / \mathrm{L})$ being tested. The final counts at the end of the fermentation process reached 7.32 to $7.68 \log \mathrm{CFU} / \mathrm{mL}$ for strain CCDM 144 and 8.00 to $9.00 \log$ CFU/mL for CCDM 922A (Table 1). The growth rate in strain CCDM 144 was not affected by the addition of $\mathrm{Na}_{2} \mathrm{SeO}_{3}$ into the M17 cultivation broth as compared with that of cells in the medium devoid of $\mathrm{Na}_{2} \mathrm{SeO}_{3}$. A similar trend was observed for strain CCDM 922A; even at the highest concentration used $(50 \mathrm{mg} / \mathrm{L})$, the viable counts decreased only slightly. Moreover, other parameters, such as $\mathrm{OD}, \mathrm{pH}$, and lactic acid production were also not influenced at any of the sodium selenite concentrations tested for either strain. These parameters are directly 
proportional to bacterial growth. For this reason the values of lactic acid, $\mathrm{pH}$ of the media and OD remained stable depending on bacterial growth. The growth of strains CCDM 144 and CCDM 922A was not inhibited by sodium selenite concentrations up to $50 \mathrm{mg} / \mathrm{L}$, which means that the used low concentrations did not have toxic effect on these strains. In further experiments the toxic selenite levels for individual strains will need to be determined.

Yang et al. [16] reported an increase in Streptococcus thermophilus and Lactobacillus delbrueckii subsp. bulgaricus counts with an increase in selenite concentration up to $80 \mu \mathrm{g} / \mathrm{mL}$; further increases in led to a decrease in cell growth. In the present study, lower selenite concentrations did not accelerate the growth of either strain, unlike the effects reported in some previous studies [16,39]. Moreover, in LAB strains tested by Shu et al. [14], viable counts decreased with the increase in sodium selenite concentration. In comparison, our results suggested that CCDM 144 may have a higher tolerance to sodium selenite than CCDM 922A because no reduction in viable counts was observed in the former strain even at the highest selenite concentration used $(50 \mathrm{mg} / \mathrm{L})$. In addition, even higher concentrations of selenite might be able to be utilized in future testing, as it appeared that the Se tolerance of CCDM144 exceed the highest concentration tested herein. The $\mathrm{pH}$ of the media remained stable regardless of the concentration of sodium selenite and the production of lactic acid did not change significantly compared to that obtained from the Se-free medium (Table 1). These values correspond to the bacterial counts. ODs were also determined by measuring the turbidity of bacterial cell suspensions spectrophotometrically at $620 \mathrm{~nm}$ to potentially also discern non-viable cells that do not form colonies on the agar using traditional microbiological methods. However, OD was not affected by the addition of Se to the culture media compared to the control (without selenite).

As reported in the literature, bacterial cells usually have a low tolerance to selenite stress (i.e., presence of inorganic forms of Se in the growth medium) and show a limited ability to reduce high concentrations of selenite. Selenite stress results in an adaptive response in lactic acid bacteria; therefore, repeated selection of Se-tolerant strains with increasing selenite stress may lead to the development of Se-enriched microorganisms for future industrial applications [40]. Accordingly, the ability to reduce high selenite concentrations to the organic Se form is limited, although substantial species- and strain-dependent differences in this capacity are observed. The results of the present study therefore suggested that $50 \mathrm{mg} / \mathrm{L}$ of sodium selenite could be regarded as the most suitable selenite concentration for Se-enrichment of S. thermophilus CCDM 144 and E. faecium CCDM 922A. For this reason, for further in vitro testing, the above concentration was used for enrichment of both of the strains. Nevertheless, higher concentrations of sodium selenite (up to $600 \mathrm{mg} / \mathrm{L}$ ) may be tolerated by some LAB strains, especially by enterococci [41]. Selenite toxicity among bacterial genera and even among individual strains may differ, depending on the enzymatic equipment they possess. Two genes present in the genome of some LAB, namely, SelA and SelD, are known to be involved in selenium metabolism and its incorporation into proteins. [41,42]. The SelD gene has been shown to be responsible in generating Se donor compounds and thus discriminating Se from sulfur [42]. The mentioned genes have been found in a recent study [41] in the genome of the species E. faecium which was also used in this study. Nevertheless, identifying the presence of genes involved in selenium metabolism in the strains CCDM 144 and CCDM 922A was out of the scope of this study.

\subsection{Effects of S. thermophillus CCDM 144 and E. faecium CCDM 922A Selenization on Antioxidant Properties}

Antioxidant properties of both strains were measured before and after Se-enrichment using the DPPH method. This method assesses the antiradical activity of pure or mixed samples and consists of the reaction of the test substance with a stable radical diphenylpicrylhydrazyl (1,1-diphenyl-2(2,4,6-trinitrophenyl) hydrazyl). The reaction was monitored spectrophotometrically by measuring the absorbance at $600 \mathrm{~nm}$. As shown in Table 2, bacterial strains CCDM 144 and CCDM 922A themselves, without Se addition, showed antioxidant activity consistent with other studies $[16,43]$. However, following Se enrichment, an increase in the mean values of antioxidant activity was observed, although this did not reach significance $(p<0.05)$. Strain CCDM 144 exhibited a higher 
antioxidant effect both before and after Se enrichment than that of CCDM 922A. The enrichment of the culture medium with inorganic Se in the form of sodium selenite led to its binding to the cells and subsequent increase in antioxidant capacity in both strain CCDM 922A (from 1.59\% to 3.14\%) and CCDM 144 (from 3.45\% to $4.06 \%$ ). It was presumed that accumulated Se in the bacterial cells was integrated into antioxidant enzymes, leading to the increase in antioxidant properties of these strains. BHT, a phenol derivative primarily used as an antioxidant and permitted as food additive E321 [44], was used as a control.

Table 2. Antioxidant capacity (\%) of the strains CCDM 144 and CCDM 922A before and after selenium-enrichment using the 2, 2-diphenyl-1-picrylhydrazyl (DPPH) method.

\begin{tabular}{cc}
\hline Strain & Antioxidant Effect DPPH (\%) \\
\hline 144 & $3.45 \pm 1.90^{\mathrm{AB}}$ \\
$144 \mathrm{Se}$ & $4.06 \pm 0.70^{\mathrm{B}}$ \\
$922 \mathrm{~A}$ & $1.59 \pm 1.73^{\mathrm{A}}$ \\
$922 \mathrm{~A} \mathrm{Se}$ & $3.14 \pm 1.06^{\mathrm{AB}}$ \\
BHT & $15.21 \pm 2.23^{\mathrm{C}}$ \\
\hline
\end{tabular}

BHT (butylated hydroxytoluene)—a positive control; the values given are the average of three measurements \pm standard deviation. $A, B, C$ data in the column with different superscripts differ $(p<0.05)$.

\subsection{Effects of S. thermophillus CCDM 144 and E. faecium CCDM 922A Selenization on Cell Surface Hydrophobicity}

Adhesion of bacteria to epithelial cells plays an important role in the colonization of intestinal epithelium by beneficial bacteria; this process may be influenced, among other factors, by cell surface hydrophobicity. The hydrophobicity of the selenized strains evaluated in the present study may also reflect the potential of strains to colonize the intestinal epithelium [45]. In the present study, both selenized strains showed higher hydrophobicity values than those of the parental strains (Table 3). In the case of $S$. thermophilus CCDM 144, the initial hydrophobicity (7.97\%) increased more than twice $(17.02 \%)$ upon selenization and in E faecium CCDM 922A, this increase was even more pronounced, from $2.13 \%$ to $17.26 \%$. To our knowledge, this is the first report related to the hydrophobicity of selenized strains of LAB. In the studies available, only the hydrophobicity of non-selenized strains was discussed. Specifically, Saini and Tomar [33] reported the hydrophobicity of LAB that had previously been confirmed as capable of excellent Se bioaccumulation, but the hydrophobicity of the strains following Se-enrichment was not presented.

Table 3. Hydrophobicity of the cell surface of selenium-enriched and parental strains of Streptococcus thermophilus CCDM 144 and Enterococcus faecium CCDM 922A.

\begin{tabular}{|c|c|}
\hline Strains & Hydrophobicity (\%) \\
\hline 144 & $7.97 \pm 2.77^{\mathrm{A}}$ \\
\hline $144 \mathrm{Se}$ & $17.02 \pm 4.16^{\mathrm{B}}$ \\
\hline $922 \mathrm{~A}$ & $2.13 \pm 0.48^{\mathrm{A}}$ \\
\hline 922A Se & $17.26 \pm 4.91^{\mathrm{B}}$ \\
\hline
\end{tabular}

The microbial adhesion to hydrocarbons (MATH) method is the most common method for hydrophobicity determination. However, the direct comparison of data obtained using this method is difficult because numerous parameters can influence the final hydrophobicity values [23]. The overall adhesion is a complex process involving multiple further parameters; for example, surface EPS, S-layer protein, and lipoteichoic acid [46]. Moreover, hydrophobicity and other cell surface properties depend on different factors such as origin, conditions of cultivation, or hydrocarbons used for testing $[33,45]$. Additionally, some LAB are able to produce EPS, a high-molecular weight polymer generated in 
the metabolic processes of some bacteria that confers the slimy consistency of dairy products and improves their viscosity and stability [47]. Some EPS can also have beneficial effects on digestion as they remain for an extended period in the digestive tract and thus provide suitable conditions for the colonization of mucous membranes by probiotic bacteria [48]. In particular, EPS production may be related to hydrophobicity and cell surface properties as a portion of the EPS can be liberated into the medium whereas capsular EPS remains bound to the cell wall of the microorganisms, which may affect cell surface properties [23]. Notably, both of the strains tested were EPS producers and we had previously confirmed that both strains were positive for the presence of eps genes encoding EPS; we also confirmed the phenotypic expression of EPS production in the form of increased viscosity of the products fermented by these strains.

The cell wall constituents and the polysaccharides associated with the bacterial cell wall and EPS also have a primary role in determining bacterial surface properties [49] in addition to the metal ion binding capacity. We considered that similar effects on the cell surface would also occur in Se-enriched bacteria. In turn, strains with the ability to biotransform inorganic Se into the organic form incorporate Se into proteins, amino acids, intracellular or extracellular nanoparticles, or potentially the bacterial EPS [50,51]. For a comprehensive assessment of the influence of Se enrichment on cell surface properties, additional methods will be necessary to allow better characterization including autoaggregation, coaggregation, or the ability to adhere to intestinal cell tissue (e.g., mixed coculture of Caco2 and HT-29 cells).

\section{Conclusions}

Significant Se uptake from the growth medium by S. thermophilus CCDM 144 and E. faecium CCDM 922A with concomitantly high biomass production suggested that these strains might be good candidates for Se enrichment. Nevertheless, further testing of their properties following Se enrichment will be necessary, such as changes in the morphology and metabolism of selenized vs. parental strains along with the detection of individual Se species (e.g., selenoamino acids, selenoproteins) into which Se is incorporated. This study revealed that several species of LAB may be suitable for Se enrichment and thus can be applied in supplementation studies. Nevertheless, further in vitro and in vivo analyses of both strains must be performed to guarantee the safety of the selenized versions of these commercial strains prior to their use in foods.

Author Contributions: Conceptualization, G.K., A.K. and I.H.; methodology, G.K., M.K., and A.K.; formal analysis, G.K. and A.K.; investigation, I.H., I.M., A.K., and M.K.; resources, G.K. and A.K.; writing-original draft preparation, G.K., A.K., I.H., I.M., and M.K.; writing—review and editing, G.K.; supervision, G.K. and A.K.; project administration, G.K. All authors have read and agreed to the published version of the manuscript.

Funding: This research was funded by the program INTER-EXCELLENCE, subprogram INTER-COST of the Ministry of Education, Youth and Sport of the Czech Republic, grant No. LTC 20014 (COST CA18113) and by the Ministry of Agriculture of the Czech Republic, Institutional support, No. MZE-RO1420.

Conflicts of Interest: The authors declare no conflict of interest.

\section{References}

1. Mrvčić, J.; Stanzer, D.; Solić, E.; Stehlik-Tomas, V. Interaction of lactic acid bacteria with metal ions: Opportunities for improving food safety and quality. World J. Microbiol. Biotechnol. 2012, 28, 2771-2782. [CrossRef]

2. Chojnacka, K.; Mikulewicz, M.; Cieplik, J. Biofortification of food with microelements. Am. J. Agric. Biol. Sci. 2011, 6, 544-548.

3. Pescuma, M.; Gomez-Gomez, B.; Perez-Corona, T.; Font, G.; Madrid, Y.; Mozzi, F. Food prospects of selenium enriched Lactobacillus acidophilus CRL 636 and Lactobacillus reuteri CRL 1101. J. Funct. Foods 2017, 35, 466-473. [CrossRef]

4. Rayman, M.P. The importance of selenium to human health. Lancet 2000, 356, 233-241. [CrossRef] 
5. Commission Regulation (EC) No 1170/2009 of 30 November 2009 Amending Directive 2002/46/EC of the European Parliament and of Council and Regulation (EC) No 1925/2006 of the European Parliament and of the Council as Regards the Lists of Vitamin and Minerals and Their Forms that can Be Added to Foods, Including Food Supplements. Available online: https://op.europa.eu/en/publication-detail/-/publication/ 45405cb0-0fc6-48ec-b8a0-8f93b50d6a82/language-en (accessed on 15 July 2020).

6. Rother, M. Selenium metabolism in prokaryotes. In Selenium; Hatfield, D.L., Berry, M.J., Gladyshev, V.N., Eds.; Springer: New York, NY, USA, 2011; pp. 457-470.

7. Zhang, B.; Zhou, K.; Zhang, J.; Chen, Q.; Liu, G.; Shang, N.; Qin, W.; Li, P.; Lin, F. Accumulation and species distribution of selenium in Se-enriched bacterial cells of the Bifidobacterium animalis 01. Food Chem. 2009, 115, 727-734. [CrossRef]

8. Shakibaie, M.; Khorramizadeh, M.R.; Faramarzi, M.A.; Sabzevari, O.; Shahverdi, A.R. Biosynthesis and recovery of selenium nanoparticles and the effects on matrix metalloproteinase-2 expression. Biotechnol. Appl. Biochem. 2010, 56, 7-15. [CrossRef]

9. Pophaly, S.D.; Poonam; Singh, P.; Kumar, H.; Tomar, S.K.; Singh, R. Selenium enrichment of lactic acid bacteria and bifidobacteria: A functional food perspective. Trends Food Sci. Technol. 2014, 39, 135-145. [CrossRef]

10. Yang, J.; Wang, J.; Yang, K.; Liu, M.; Qi, Y.; Zhang, T.; Fan, M.; Wei, X. Antibacterial activity of selenium-enriched lactic acid bacteria against common food-borne pathogens in vitro. J. Dairy Sci. 2018, 101, 1930-1942. [CrossRef]

11. Zare, H.; Vahidi, H.; Owlia, P.; Khujin, M.H.; Khamisabad, A. Yeast enriched with selenium: A promising source of selenomethionine and seleno-proteins. Trends Pept. Protein Sci. 2017, 1, 130-134.

12. Kieliszek, M.; Błażejak, S.; Gientka, I.; Bzducha-Wróbel, A. Accumulation and metabolism of selenium by yeast cells. Appl. Microbiol. Biotechnol. 2015, 99, 5373-5382. [CrossRef]

13. Schrauzer, G.N. Selenium yeast: Composition, quality, analysis, and safety. Pure Appl. Chem. 2006, 78, 105-109. [CrossRef]

14. Shu, G.; Mei, S.; Chen, L.; Zhang, B.; Guo, M.; Cui, X.; Chen, H. Screening, identification, and application of selenium-enriched Lactobacillus in goat milk powder and tablet. J. Food Process. Preserv. 2020, 44, e14470. [CrossRef]

15. Xu, X.; Bao, Y.; Wu, B.; Lao, F.; Hu, X.; Wu, J. Chemical analysis and flavor properties of blended orange, carrot, apple, and Chinese jujube juice fermented by selenium-enriched probiotics. Food Chem. 2019, 289, 250-258. [CrossRef] [PubMed]

16. Yang, J.; Li, Y.; Zhang, L.; Fan, M.; Wei, X. Response surface design for accumulation of selenium by different lactic acid bacteria. 3 Biotech 2017, 7, 52. [CrossRef] [PubMed]

17. Ouwehand, A.C.; Vesterlund, S.A. Antimicrobial components from lactic acid bacteria. Food Sci. Technol. 2004, 139, 375-396.

18. Hyrslova, I.; Krausova, G.; Bartova, J.; Kolesar, L.; Jaglic, Z.; Stankova, B.; Curda, L. Characterization of Enterococcus faecium CCDM 922 in respect of its technological and probiotic properties. Int. J. Curr. Microbiol. Appl. Sci. 2016, 5, 474-482. [CrossRef]

19. Li, B.; Zhan, M.; Evivie, S.E.; Jin, D.; Zhao, L.; Chowdhury, S.; Sarker, S.K.; Huo, G.; Liu, F. Evaluating the safety of potential probiotic Enterococcus durans KLDS6.0930 using whole genome sequencing and oral toxicity study. Front. Microbiol. 2018, 9, 1943. [CrossRef]

20. Nascimento, L.C.S.; Casarotii, S.N.; Todorov, S.D.; Penna, A.L.B. Probiotic potential and safety of enterococci strains. Ann. Microbiol. 2019, 69, 241-252. [CrossRef]

21. Herman, L.; Chemaly, M.; Cocconcelli, P.S.; Fernandez, P.; Klein, G.; Peixe, L.; Prieto, M.; Querol, A.; Suarez, J.E.; Sundh, I.; et al. The qualified presumption of safety assessment and its role in EFSA risk evaluations: 15 years past. FEMS Microbiol. Lett. 2019, 366, fny260. [CrossRef]

22. Salminen, S.; von Wright, A.; Ouwehand, A. Lactic acid bacteria. In Microbiological and Functional Aspects, 3rd ed.; Salminen, S., von Wright, A., Eds.; Marcel Dekker, Inc.: New York, NY, USA, 2004; p. 633.

23. Nachtigall, C.; Weber, C.; Rothenburger, S.; Jaros, D.; Rohm, H. Test parameters and cell chain length of Streptococcus thermophilus affect the microbial adhesion to hydrocarbon assay: A methodical approach. FEMS Microbiol. Lett. 2019, 366, fnz150. [CrossRef]

24. Weisburg, W.G.; Barns, S.D.M.; Pelletier, D.A.; Lane, D.J. $16 S$ ribosomal DNA amplification for phylogenetic study. J. Bacteriol. 1991, 173, 697-703. [CrossRef] [PubMed] 
25. Altschul, S.F.; Madden, T.L.; Schäffer, A.A.; Zhang, J.; Zhang, Z.; Miller, W.; Lipman, D.J. Gapped BLAST and PSI-BLAST: A new generation of protein database search programs. Nucleic Acids Res. 1997, 25, 3389-3402. [CrossRef] [PubMed]

26. Stackebrandt, E.; Goebel, B.M. Taxonomic Note: A place for DNA-DNA reassociation and 16S rRNA sequence analysis in the present species definition in bacteriology. Int. J. Syst. Evol. Microbiol. 1994, 44, 846-849. [CrossRef]

27. Eichler, Š.; Kaňa, A.; Kalousová, M.; Vosmanská, M.; Korotvička, M.; Zima, T.; Mestek, O. Speciation analysis of selenium in human urine by liquid chromatography and inductively coupled plasma mass spectroetry for monitoring of selenium in body fluids. Chem. Spec. Bioavail. 2015, 27, 127-138. [CrossRef]

28. Rajab, S.; Tabandeh, F.; Shahraky, M.K.; Alahyaribeik, S. Effect of Lactobacillus cell size on probiotic characteristics. Anaerobe 2020, 62, 102103. [CrossRef]

29. Son, S.H.; Yang, S.J.; Jeon, H.L.; Yu, H.S.; Lee, N.K.; Park, Y.S.; Paik, H.D. Antioxidant and immunostimulatory effect of potential probiotic Lactobacillus paraplantarum SC61 isolated from Korean traditional fermented food, jangajji. Microb. Pathog. 2018, 125, 486-492. [CrossRef]

30. Vinderola, C.; Medici, M.; Perdigón, G. Relationship between interaction sites in the gut, hydrophobicity, mucosal immunomodulating capacities, and cell wall protein profiles in indigenous and exogenous bacteria. J. Appl. Microbiol. 2004, 96, 230-243. [CrossRef]

31. Pieniz, S.; Andreazza, R.; Mann, M.B.; Camargo, F.; Brandelli, A. Bioaccumulation and distribution of selenium in Enterococcus durans. J. Trace Elem. Med. Biol. 2017, 40, 37-45. [CrossRef]

32. Xia, K.S.; Chen, L.; Liang, J.Q. Enriched selenium and its effects on growth and biochemical composition in L. bulgaricus. J. Agric. Food Chem. 2007, 55, 2413-2417. [CrossRef]

33. Saini, K.; Tomar, S.K. In vitro evaluation of probiotic potential of Lactobacillus cultures of human origin capable of selenium bioaccumulation. LWT 2017, 84, 497-504. [CrossRef]

34. Adadi, P.; Barakova, N.V.; Muravyov, K.Y.; Krivoshapkina, E.F. Designing selenium functional foods and beverages: A review. Food Res. Int. 2019, 120, 708-725. [CrossRef]

35. Alzate, A.; Canas, B.; Perez-Munguia, S.; Hernandez-Mendoza, H.; Perez-Conde, C.; Gutierez, A.M.; Camara, C. Evaluation of the inorganic selenium biotransformation in selenium-enriched yogurt by HPLC-ICP-MS. J. Agric. Food Chem. 2007, 55, 9776-9783. [CrossRef] [PubMed]

36. Alzate, A.; Fernandez-Fernandez, A.; Perez-Conce, M.C.; Gutierez, A.M.; Camara, A. Comparison of biotranformation of inorganic selenium by Lactobacillus and Saccharomyces in lactic fermentation process of yoghurt and kefir. J. Agric. Food Chem. 2008, 56, 8728-8736. [CrossRef] [PubMed]

37. Kousha, M.; Yeganeh, S.; Amirkolaie, A.K. Effect of sodium selenite on the bacteria growth, selenium accumulation, and biotransformation in Pediococcus acidilactici. Food Sci. Biotechnol. 2017, 26, 1013-1018. [CrossRef]

38. Kurek, E.; Ruszczynska, A.; Wojciechowski, M.; Łuciuk, A.; Michalska-Kacymirow, M.; Motyl, O.; Bulska, E. Bio-transformation of selenium in Se-enriched bacterial strains of Lactobacillus casei. Rocz. Panstw. Zakl. Hig. 2016, 67, 253-262. [PubMed]

39. Peñas, E.; Martinez-Villaluenga, C.; Frias, J.; Sánchez-Martínez, M.J.; Pérez-Corona, M.T.; Madrid, Y.; Cámara, C.; Vidal-Valverde, C. Se improves indole glucosinolate hydrolysis products content Se-methylselenocysteine content, antioxidant capacity, and potential anti-inflammatory properties of sauerkraut. Food. Chem. 2012, 132, 907-914. [CrossRef]

40. Pusztahely, T.; Kovács, S.; Pócsi, I.; Prokisch, J. Selenite-stress selected mutant strains of probiotic bacteria for Se source production. J. Trace Elem. Med. Biol. 2015, 30, 96-101. [CrossRef]

41. Estrada, A.M.; Olivares, L.G.G.; Lopez, E.C.; Serrano, G.R. SelA and SelD genes involved in selenium absorption metabolism in lactic acid bacteria isolated from Mexican cheeses. Int. Dairy J. 2020, 103, 104629. [CrossRef]

42. Zhang, Y.; Turanov, A.A.; Hatfield, D.L.; Gladyshev, V.N. In silico identification of genes involved in selenium metabolism: Evidence for a third selenium utilization trait. BMC Genom. 2008, 9, 251. [CrossRef]

43. Amaretti, A.; di Nunzio, M.; Pompei, A.; Raimondi, S.; Rossi, M.; Bordoni, A. Antioxidant properties of potentially probiotic bacteria: In vitro and in vivo activities. Appl. Microbiol. Biotechnol. 2013, 97, 809-817. [CrossRef] 
44. European Parliament and Council Directive No 95/2/EC of 20 February 1995 on Food Additives Other than Colours and Sweeteners. Available online: https://eur-lex.europa.eu/legal-content/EN/TXT/?uri=CELEX: 32006L0129 (accessed on 15 July 2020).

45. Iyer, R.; Tomar, S.K.; Kapila, S.; Mani, J.; Singh, R. Probiotic properties of folate producing Streptococcus thermophilus strains. Food Res. Int. 2010, 43, 103-110. [CrossRef]

46. Pan, M.; Kumaree, K.K.; Shah, N.P. Physiological changes of surface membrane in Lactobacillus with prebiotics. J. Food Sci. 2017, 82, 744-750. [CrossRef] [PubMed]

47. Guo, Y.; Pan, D.; Li, H.; Sun, Y.; Zeng, X.; Yan, B. Antioxidant and immunomodulatory activity of selenium exopolysaccharide produced by Lactococcus lactis subsp. Lactis. Food Chem. 2013, 138, 84-89. [CrossRef] [PubMed]

48. Korakli, M.; Pavlovic, M.; Gänzle, M.G.; Vogel, R.F. Exopolysaccharide and ketose production by Lactobacillus sanfranciscensis LTH 2590. Appl. Environ. Microbiol. 2003, 69, 2073-2079. [CrossRef]

49. Ruas-Madiedo, P.; Hugenholtz, J.; Zoon, P. Overview of the functionality of exopolysaccharides produced by lactic acid bacteria. Int. Dairy J. 2002, 12, 163-171. [CrossRef]

50. Mörschbächer, A.P.; Dullius, A.; Dullius, C.H.; Brandt, C.R.; Kuhn, D.; Brietzke, D.T.; Malmann Kuffel, F.J.; Etgeton, H.P.; Altmayer, T.; Gonçalves, T.E.; et al. Assessment of selenium bioaccumulation in lactic acid bacteria. J. Dairy Sci. 2018, 101, 10626-10635.

51. Palomo-Siguero, M.; Gutiérrez, A.M.; Pérez-Conde, C.; Madrid, Y. Effect of selenite and selenium nanoparticles on lactic bacteria: A multi-analytical study. Microchem. J. 2016, 126, 488-495. [CrossRef]

(C) 2020 by the authors. Licensee MDPI, Basel, Switzerland. This article is an open access article distributed under the terms and conditions of the Creative Commons Attribution (CC BY) license (http://creativecommons.org/licenses/by/4.0/). 